\title{
Good Practices and Actions for Sustainable Municipal Solid Waste Management in the Tourist Sector
}

\author{
Ramona Giurea 1,2 (1), Ilaria Precazzini ${ }^{2}$, Marco Ragazzi ${ }^{2}$, Moise Ioan Achim ${ }^{1}$, \\ Lucian-Ionel Cioca ${ }^{1,3}$ (D) , Fabio Conti ${ }^{4}$, Vincenzo Torretta 4 (D) and Elena Cristina Rada ${ }^{1,2,4, * \text { (ID) }}$ \\ 1 Department of Industrial Engineering and Management, Lucian Blaga University of Sibiu, \\ 550024 Sibiu, Romania; ramona.giurea@ulbsibiu.ro (R.G.); achimmoise@yahoo.com (M.I.A.); \\ lucian.cioca@ulbsibiu.ro (L.-I.C.) \\ 2 Department of Civil Environmental and Mechanical Engineering, University of Trento, 38123 Trento, Italy; \\ ilaria.precazzini@gmail.com (I.P.); marco.ragazzi@unitn.it (M.R.) \\ 3 Academy of Romanian Scientists, 050094 Bucharest, Romania \\ 4 Department of Theoretical and Applied Sciences, Insubria University, 21100 Varese, Italy; \\ fabio.conti@uninsubria.it (F.C.); vincenzo.torretta@uninsubria.it (V.T.) \\ * Correspondence: elena.rada@unitn.it or elena.rada@uninsubria.it, Tel.: +39-046-128-2613
}

Received: 11 June 2018; Accepted: 10 August 2018; Published: 13 August 2018

\begin{abstract}
This paper deals with waste management in the tourism sector, specifically in the agro-tourism structures. Two regions of Romania and Italy have been considered as case studies in order to promote good practices and actions for sustainable municipal solid waste management. Specific criteria to adopt for the sustainable consumption of beverages and food and for the sustainable use of packaging of various types have been analyzed and suggested. The adoption of an indicator at the level of the single tourist structure has been proposed to help self-analysis that is aimed at setting the priorities of intervention for improving its environmental sustainability.
\end{abstract}

Keywords: actions; good practices; management; municipal solid waste; sustainability; tourism

\section{Introduction}

Nowadays, sustainable development with particular reference to environmental quality and protection is an important objective for the European Union (EU) [1]. The United Nations (UN), through the Division for Sustainable Development (DSD) has reported that one of its goals is to ensure a sustainable consumption and production. The direction is not only aimed at reducing the use of resources and pollution, but also at taking an overview of the use of products on their life cycles [2]. The most commonly used definition of sustainable development is the one presented in the report of the World Commission on Environment and Development (1987)—the Brundtland Report [3]: sustainable development is "development that meets the needs of the present without compromising the ability of future generations to meet their own needs". The present article focuses on environmental sustainability because the environment represents the "raw material", the object and scope of tourism activity. Examples of environmentally sustainable practices include waste prevention, recycling programs, composting, etc.

In this frame, sustainable municipal solid waste (MSW) management [4] under a circular economy view has become a very important goal in the EU and non-EU countries [5-8]. The tourism sector contributes to its environmental and economic impacts through accommodation (energy consumption, wastewater generation, and MSW production), restaurant services, and transport (local transport and traffic between tourists' provenance and destination) [9-18].

According to the European Parliament, tourism represents the third most significant socio-economic activity in the EU. Agro-tourism is part of this sector, and this tourist offer includes 
various activities: accommodation, breakfast and restaurant services, and leisure activities (sports and educational-recreational activities). In most of these cases, agro-tourism structures are a family business. Through those activities, the farmers contribute to promote their land and the sale of their own home-made products, adding value to local agricultural production [19-21].

The tourist reception structure in agro-tourism is usually named an "agro-tourist boarding house" (ABH). The classification of tourism structures represents a systematic collection of data regarding their comfort level, the standards of their tourist products, the quality of their services, etc.

Regarding the agro-tourism categorization, Phillip et al. [22] delivers a detailed analysis of the theoretical and practical documentation. In summary, this categorization sets up a five-step classification were agro-tourism is unfolding in a:

(a) Non-working farm, where the place of residence is a farm that is dedicated to rural activities and that is presently is not connected anymore with farming elements;

(b) Working farm with passive contact by tourists, where the working farm provides an exclusive framework for tourism;

(c) Working farm, with indirect contact by tourists-local products and services are included in the consumption process of the tourists;

(d) Working farm, with direct contact but indirect participation by the tourists (e.g., farming demonstrations regarding different aspects of rural life);

(e) Working farm, with direct contact by the tourists by participation in rural activities that are developed within the farm.

More specifically, agro-tourism can take mixed forms of activities, with multiple combinations between them. Examples of agro-tourism forms are [23]:

- "u-pick" operations or pick your own (PYO): operations for harvesting fresh fruits and vegetables;

- on-farm produce stands: retailing already-harvested fresh fruits, vegetables, and value-added farm products (jams, sauces, etc.);

- on-farm restaurant, dinners, bakeries;

- instructive/educational farm tours and interactive demonstrations;

- on-farm activities for children/kids and adults; animal exhibits;

- on-farm bed and breakfasts, pensions, agro-tourism boarding houses (ABHs), cottages, or campgrounds;

- hands-on farm tasks as milking cows, feeding farm animals, collecting eggs, etc.;

- vineyards and wineries;

- on-farm festivals and events;

- viewing and photography.

According to the United Nations World Tourism Organisation (UNWTO), Europe was the most frequently visited region in the world in 2016; more nights were spent in tourist accommodation establishments located in rural areas than in cities; Europe represented a percentage that was close to $45 \%$ of the total nights spent by tourists in 2014 [24]. In Romania and Italy, the agro-tourism sector is growing $[25,26]$. Romania, since 1989 , after the communist period, started to implement legislation in the tourism sector, whereas in Italy, rural areas and farms are involved in a program of development through diversification into new activities such as agro-tourism $[27,28]$. Moreover, Romania is a country that has recently entered into the EU, whilst Italy is an old member with experience in the regulations of this sector. Due to its presence in the European Union over a longer time, Italy could be a reference for Romania to understand whether and how a longer experience under the regulatory context of the EU helps the tourist sector to be more sustainable.

Presently, one of the major challenges for the tourism industry is MSW [29]. Evaluations report that in Europe, an international tourist generates on average approximately $1 \mathrm{~kg}$ of MSW per day. 
According to the United Nations Environment Programme's assessment, international tourists of Europe generate around 2.8 million tons of MSW. Moreover, domestic and international tourists' MSW production will rise to about 8.4 million tons yearly in 2020 (with an increase of more than $60 \%$ in two decades) [30].

Among the most important problems the EU has faced within the past decades, there is the differing development of rural and urban regions. Farming and agriculture are a valuable sector of human activity, but their contribution to the national gross domestic product has constantly decreased. Various strategies were defined within the EU to stimulate the development of rural regions, to strengthen the self-sustainable economies through strong entrepreneurial rural business solutions. With the decline of farm revenues, tourism has increased rapidly in the rural regions. In this context, the agro-tourism sector has newly attained more attention due to the demographic tendency across Europe, but also worldwide.

Research suggests that the agro-tourism sector is growing [31,32]. Thus, to an extent within agro-tourism development, this article contributes to an approach that is based on sustainable management.

The aim of the present article is to propose, develop, and improve the sector of solid waste through individuation and the proposal of good practices and actions. As a result of this overview, an indicator has been proposed to help the managers of an agro-tourism business to perform a self-analysis of waste management in their structures, focused on waste prevention. Organizations in charge of the regions for the two selected case studies (Trentino province and Sibiu county) demonstrated both a lack of integrated vision from an environmental point of view. This was in place in spite of the enhanced management of the environment in one of the two regions involved. The adoption of this indicator, which is planned as a second step in the present research, is aimed to support the managers in a pathway of sustainability.

\section{Materials and Methods}

\subsection{Selection of the Case Studies}

The present research is focused on Romania and Italy because of the pronounced similitude with other countries of the EU, and their features regarding the cultural and spiritual side. Both countries have tourism heritage in the winter and summer seasons due to their climate, geographic development and architectonic heritage. With the decline of farm revenues, tourism, as an added activity, has increased rapidly in the rural regions. In this context, the agro-tourism sector has newly attained more attention due to its demographic tendency across Europe. Therefore, the spread of rural regions in both countries (indicating that Italy has $45.5 \%$ rural land and Romania has 59.8\% rural land) [33] has important potential for its development because of the existence of rural areas, their climate, their geographic position, and their natural and cultural heritage.

Italian and Romanian tourism (also agro-tourism) can also positively influence environmental protection, reducing the production of waste and polluting emissions through proper and suitable management of the sectors of waste, water, and energy resources [22,23,30,34-39].

The term "agro-tourism structures" will be used to include all the meanings of 'farm locations' identified by [22], highlighting those accommodation facilities where tourists are involved directly and are active in agricultural activities, rural housing, and crafting activities, without harming the natural environment. Specifically, in this article, two case studies have been selected: Italy through the province of Trento (Trentino), and Romania through the Sibiu County; both territories are known as national and international tourist destinations and present similarities in size (about 6200 and $5400 \mathrm{~km}^{2}$ respectively), population (about 540,000 and 450,000 inhabitants respectively), and orography [40-43]. 


\subsection{Research Development}

The present article concerns the first step of a two-step research plan based on the two selected case studies. The two steps are:

I. Waste management criteria and emerging needs from selected case studies (this article)

- $\quad$ Classification aspects and the relationship with the environment

- $\quad$ Good practices and actions for sustainable waste management

- $\quad$ Role of legislation in the case studies

- Proposal for a new indicator for waste management in agro-tourism structures, developed to analyze all the good practices and actions that emerged in this first step from the two case studies

II. Administration of a questionnaire for the assessment of the proposed indicator in the two case studies (planned article)

Two organizations were involved in the case studies: The Economy and Rural Policy Office of the Autonomous Province of Trento and the Sibiu County Tourism Association. Both of the local administrations supported the present research by making information available on the structures of the two territories, and on the approach that was used to disseminate sustainable criteria for management.

The accessed information was available in form of raw databases (Excel files not yet organized for easy data extraction) and printed dissemination documents.

The collected information was organized in a table of practices and actions that aimed to reduce waste production in these structures. A quantification of the management quality of the structure from the waste perspective was based on the level of implementation of single actions. With regard to this, the proposal of an indicator was set to support tourism managers to perform a self-analysis (self-certification) on waste reduction. In the scientific literature, some indexes and indicators concerning MSW management in EU and non-EU countries, and under different sites can be found [44-47], but they do not zoom on single structures like agro-tourism. To the authors' knowledge, the self-certification that can be obtained from the adoption of the proposed indicator is not in conflict with other certifications.

\section{Results}

The following results were obtained thanks to the collaboration of the Economy and Rural Policy Office of the Autonomous Province of Trento and the Sibiu County Tourism Association.

\subsection{Classification Aspects}

In Italy and Romania, tourism and agro-tourism structures are classified through a number of daisies (a scale from 1 to 5); this characteristic numbering is assigned to each structure according to a local law (province or country). The criteria for the calculation of the points that result in a certain number of flowers consider the entrepreneurship and landscape contexts of the $\mathrm{ABH}$, the general quality of management of the farm, the accommodation services and commodities, the catering services, the presence and the level of recreational activities, the agricultural activities, and the typical products of the farm. In the Province of Trento, a total of 441 classified agro-tourism businesses are active; conversely, in Sibiu County, only 118 structures can be counted [48,49]. The issue of the "environment" is close to being absent in this classification. However, all of the tourist structures in Trentino, as well as in Sibiu County, have to comply with the instructions of the local authorities that are responsible for the local waste management service. The MSW that is produced depends mainly on the size of the structure in terms of accommodation capacity (namely, the number of beds, and seats at tables for the restaurant service). The quantity of produced waste must be linked to the number of days per year during which the accommodation is open. Various types of services can be 
available, depending on the specific structure of lodging in apartments or rooms, camping activities, breakfast or restaurant services, and recreational, cultural, and educational activities that can be offered to customers. The waste generated in these ambits can be assimilated to domestic urban waste, as it mainly concerns the organic fraction, packaging, plastic, paper, cardboard, glass, tins, and undifferentiated waste.

\subsection{Good Practices and Actions}

In order to perform improvements of waste production in the tourist structures, the first aspect aims at identifying and carrying out good practices and actions, in order to promote waste reduction actions as much as possible. They should be accomplished before dealing with the problems that are connected to proper and efficient waste differentiation and disposal. These objectives can be achieved by diffusing a consciousness attitude about the various consequences of the consumption style among workers and tourists.

According to what was learnt in the two case studies, the possibility of reducing the amount of waste generated in the tourism structures can be put into practice through reasonable choices concerning, first of all, the structure's supplies; this involves the restaurant service, as well as the different services that can be offered to tourists during the stay. Improvements are obtainable in several ambits, and this results in reduced waste production without compromising the quality of the service.

Numerous and simple actions can be obtained in the restaurant, breakfast, or bar service. These include, for example, the offer of bulk products (or with less packaging) and the removal of disposable products and food samples such as jams, honey, butter, cereals, and sugar, by replacing them with, bulk products stored in dispensers. It is also advisable to avoid the sale of plastic water bottles and drink bottles, single-dose juices and tins, offering alternatively on-fountain drinks, returnable bottled drinks, or at least family-sized or large packs. In addition to this, it is better to limit packaged food items by replacing them with homemade products, especially for breakfast services. Concerning this, in Trentino, Italy, the regulations of the agro-tourism's sector state that a minimum percentage of the products that are offered must be produced by the farm itself, as a way of reducing the required packaging from items that are acquired outside of the region.

Measures to reduce the waste production can also be adopted in rooms and bathrooms; personal hygiene products in packet samples should be avoided, and rechargeable dispensers should be alternatively proposed. Moreover, disposable plastic glasses should be replaced with those made of glass, and it is preferable to limit courtesy products that are offered to guests through gadgets, and to provide the same services through centralized systems.

Concerning the routine maintenance of the various areas (e.g., where remote controls are used), it is advisable to gradually replace traditional batteries with rechargeable ones in order to minimize hazardous waste generation.

The choice of the alternative products has to be careful and oriented to the reduction of the amount of waste produced; choices also have to be supported by a service that shares the same goals. Some examples can include the use of re-usable items for the breakfast and restaurant services as well as in the rooms: disposable paper tablecloths and napkins should be replaced by durable products: cloth kitchen cloths, glass and porcelain dishes; if this is not possible, eco-friendly compostable, biodegradable disposable dishes can be used according to the specification EN13432 [50].

For cleaning activities, it is better to use bulk detergents that can be bought from distributors that offer automatic bottle or tank dispensers; these large quantities can then be poured out in case of need.

The choice of using tap water, bulk products, or those in large packs is an advantageous solution from the environmental point of view, as well as from the economic side. Furthermore, the use of short food supply chain products is a way to reduce transport costs and necessary packaging, as well as to support the local economy with its relative suppliers. 
By carrying out the proposed solutions, it is possible to achieve a significant reduction of waste; this is especially true for the amount of packaging and plastic waste; in any case, it is fundamental to educate guests and workers on the correct choice or use of products.

In addition to traditional waste, workers or guests may have to get rid of hazardous or uncommon wastes such as batteries, expired medicines, spray cans, printer cartridges, or energy-saving light bulbs. For these types of waste, considering the particular features and their infrequent production, it is preferable to hand them over to staff that directly deal with the proper delivery to collection centers.

Within the ambit of tourism structures, a significant contribution to waste management can be given by adopting home composting for the organic fraction (OF) of produced MSW [51-53]. Domestic food waste or green and woody organic substances such as pruning residues can be used for this practice. Autonomous composting, when officially recognized as a suitable management option, will allow for economic benefits if the local authority in force for waste management decides to reduce the fee for waste disposal when this strategy is performed. Instead of composting, part of the kitchen waste can be used to feed farmyard animals.

Products that are generally used in accommodation facilities are summarized in Table 1, along with some practices and actions that can help to reduce waste production.

Table 1. Practices and actions to reduce waste production in tourism structures.

\begin{tabular}{cll}
\hline Main Consumer Goods & Practices & Actions \\
Food and drink & $\begin{array}{c}\text { Setting up a separate collection for } \\
\text { packaging waste, including home } \\
\text { composting in waste } \\
\text { management options }\end{array}$ & $\begin{array}{l}\text { Preferring local products; choosing bulk } \\
\text { products; preferring glass to plastic; } \\
\text { reducing the volume of waste; avoiding } \\
\text { sample packs and disposable products; } \\
\text { using re-usable bottles, dishes, and } \\
\text { containers; allowing and encouraging the } \\
\text { taking away of leftover food; implementing } \\
\text { home composting. Implementing separate } \\
\text { collection for packaging waste }\end{array}$ \\
\hline Paper & $\begin{array}{l}\text { Setting up a separate collection for } \\
\text { paper waste }\end{array}$ & $\begin{array}{l}\text { Implementing a separate collection for } \\
\text { paper waste }\end{array}$ \\
\hline Hygiene products & & $\begin{array}{l}\text { Avoiding sample packs } \\
\text { Detergents }\end{array}$ \\
\hline $\begin{array}{c}\text { Special products (e.g., batteries, } \\
\text { toner, medicines, light bulbs, etc.) }\end{array}$ & $\begin{array}{l}\text { Implementing recycling centers for the } \\
\text { direct delivery of these products }\end{array}$ & $\begin{array}{l}\text { Preferring bulk products with refillable } \\
\text { containers }\end{array}$ \\
\hline $\begin{array}{c}\text { Breakfast and restaurant service } \\
\text { conferring of these products to the recycling } \\
\text { center; preferring rechargeable batteries. }\end{array}$ \\
\hline
\end{tabular}

If the tourism structure is far from built-up areas, additional complications may arise. In some cases, for example, workers have to personally carry separate and undifferentiated waste to the nearest waste collection center. This may correspond with the road waste containers in the nearest built-up area, or directly with the recycling center that belongs to the municipality.

\subsection{Role of Legislation}

In addition to the measures that allow the reduction of waste production, tourism structures have to carry out waste separation and a proper selective collection (SC). The legislation for the proposed Italian case study asks for a high SC of MSW on the entire provincial territory [15]. In Romania, even if the EU legislation regarding MSW management and SC implementation is enforced, for many reasons (lack of knowledge, lack of treatment plants, etc.) the SC efficiency in tourism structures is still very low [51]. A reason is the fact that Romania only entered into the EU in 2007.

Selective collection is a widespread (compulsory) practice in the EU territories, although some countries turn out to be less virtuous than others in terms of separation. Even if most guests know this habit, it is good that tourist structures emphasize the importance of these practices, both when 
guests are welcomed to the accommodation facilities, and through multi-language paper and digital information, in order to illustrate clearly the different fractions that have to be separated. Thus, tourists can personally differentiate their waste products. These actions contribute to the aim of reducing the production of undifferentiated waste.

An important difference that emerged from the comparison of the Italian and Romanian case studies concerns the method of calculating the fee for waste management. In the case of Trentino, in agreement with a modern approach to management [5], the system is based on a punctual tariff that is calculated depending on the amount of non-differentiated waste that is delivered by a user. Fines are applied if the differentiated streams are of bad quality. In this way, the better a user makes their SC, the lower that they need to pay. The system works, as demonstrated by the percentage of SC that was reached in 2017 in the province (around 80\%), and the good quality of the separated streams. On the contrary, the Sibiu case study is not related to the concept of punctual tariffs. The lower SC efficiency can also be explained by that.

\subsection{A Proposal}

Agro-tourism managers need specific tools to keep the environmental impact of the structures under control. As the sector of waste management is traditionally oriented to wide-scale indices and indicators [46-53], an original indicator has been set to take into account the above mentioned issues. Items listed in Table 1, taken from the analysis of the good practices found in the two case studies, have been reorganized in two classes: actions concerning food and drink, and other actions, in order to be integrated into a waste indicator. The value of each item can range from 0 to 1 .

Figure 1 reports a demonstration on how this indicator must be used at an agro-tourism structure. Values must be assigned as explained in the following parentheses: food and drink implemented (1), partially implemented (0.5), or non-implemented (0) actions; other implemented (1), partially implemented (0.5), or non-implemented (0) actions. The area to the right of the red lines (border included) concerns food and drink actions [54]. The priority in the example reported in Figure 1 should be the adoption of refillable containers for bulk detergents.

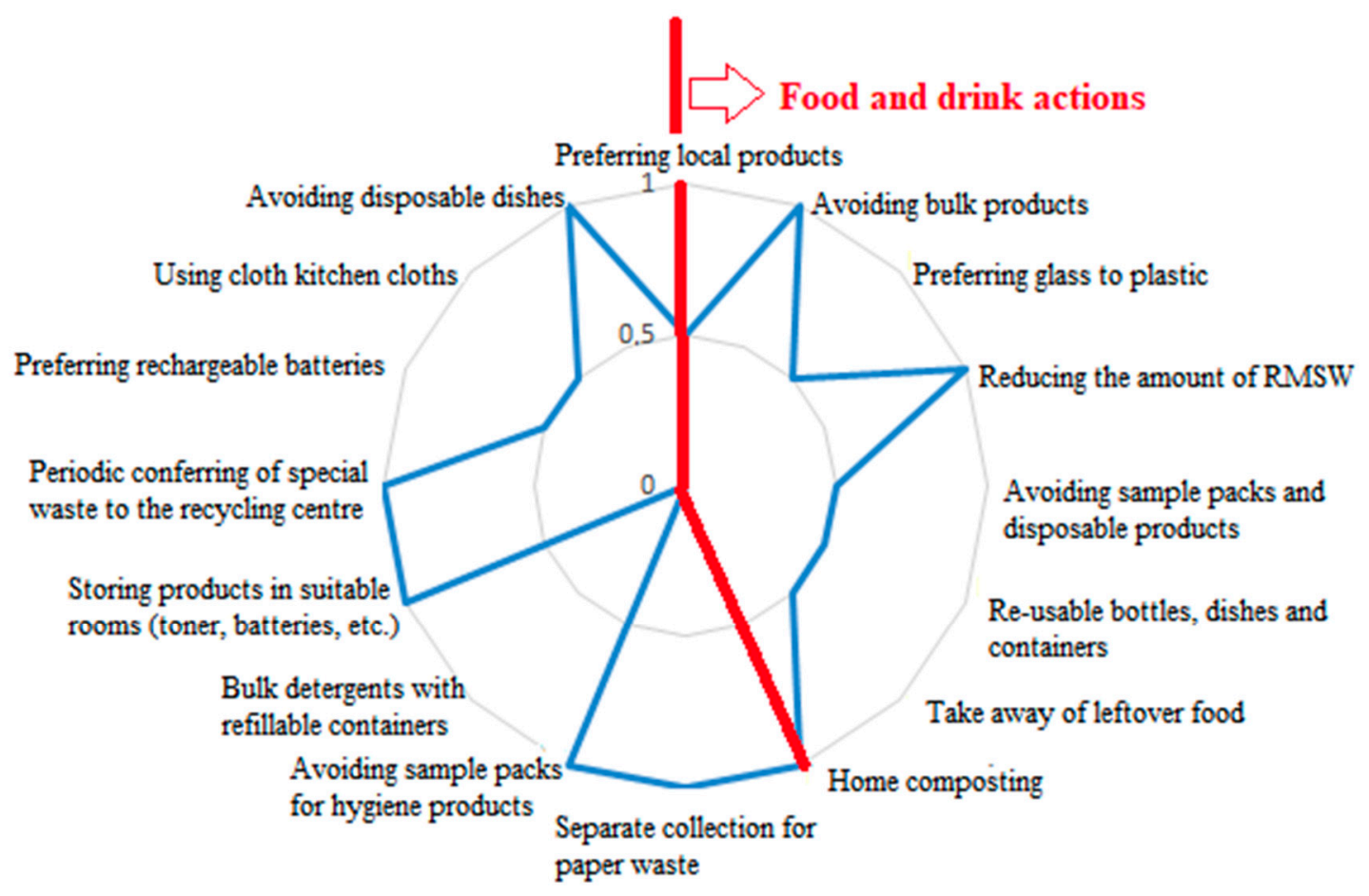

Figure 1. Example of adoption of the proposed indicator. 
Concerning the single items, the indicator does not point out specific priorities, as all the criteria must be complied with.

The use of the proposed indicator has been planned for the second step of this research, to be presented in another article. Thanks to the agreements with the local authorities and the availability of databases with contact data, the indicator will be submitted by emails, under their patronage, to persons in charge of the agro-tourism structures in the two case studies, in order to verify the level of adoption of the criteria that are presently advised by the same authorities. The adoption at each structure will be on a voluntary basis. Data will also allow for the verification of variances within the regions. Moreover, the option of assuming specific weights for each item of the indicator will be analyzed through life cycle analysis, also taking the externality costs into account [55].

\section{Discussion}

Tourism structures produce waste that can be assimilated into urban waste. Most of the waste belongs to the categories of the organic fraction, cardboard, paper, glass, tins, plastic or packaging, and undifferentiated waste [56].

On the contrary, the production of wastes that belong to other categories is uncommon. With regard to the most common types of waste, it is useful to assist guests and to give them clear and accurate information about the correct separation of the different fractions.

The assisted waste separation can take place with printed instructions and images placed near the waste containers but it can also become an interactive opportunity through which guests have the possibility, by connecting to the tourism structure website, to find a section that is dedicated to the separate collection instructions. In this way, people can know with certainty where a certain type of waste has to be placed. It is useful that instructions, both in printed and digital forms, could give information about the color that is associated with a certain type of waste; this color should be also associated with the one of the containers in the structure. Further information could be given through simple drawings representing categories of products, or through an exhaustive and detailed list of the waste that can be placed into the suitable containers. All of this information has to be displayed in different languages.

Along with the concrete actions being carried out in the tourist structures, practices that are aimed at reducing waste production, even during tourist walking-tours, should be properly promoted (e.g., using re-usable containers for food and drink).

Additionally, it is important to educate tourists to respect the environment, and to emphasize the importance of not littering: they must bring their waste back with them. This aspect is particularly relevant, given that along excursion footpaths or in rural areas, waste collection is much more difficult compared with those in urban contexts. These practices are important for aesthetic reasons, as well as for the protection of aquifers and superficial water bodies.

The proposed indicator has been developed to give an overview on waste reduction strategies that are applied in a structure. The required information is easy to collect by the manager of the structures, thus a self-analysis that can be performed with reduced effort. Apart from promoting their land and the sale of their own home-made products [19-21], by this indicator, the managers can promote their environmental management.

The agro-tourism sector has the capability to connect the economic, socio-cultural, and environmental elements of sustainability by adding to their mutual improvement. This sector is an economic activity that depends on the existence of the environment, cultures, and rural communities. Thus, the agro-tourism sector is a link to the challenges of socio-cultural and environmental impacts.

By introducing the concept of sustainability in agro-tourism, it is important to set out and implement a sustainable mode of development for agro-tourism activities. This article contributed to this. By adopting a new model of management, new concepts related to production, consumption, and ethics, etc., could be introduced into the structure, which could favor their spread at an international level. To accomplish those objectives, fundamental collaboration between farmers, 
tourists, and experts in the field is needed, by setting up policy makers. This will lead to benefits on the agro-tourism sector development in an eco-friendly environment, by achieving sustainable developments.

Nevertheless, promoting and developing sustainable management in agro-tourism can be a reference and lead for: (a) sustainable use of resources, (b) sustainable development of agro-tourism, and (c) the improvement of efficiency in agro-tourism activities. It is problematic to implement this in agro-tourism outside of suitable legislation, with policies being essential for supporting agro-tourism. Stringent regulation of waste management in Trentino demonstrates that a legislative frame helps.

Sustainable development in agro-tourism can be viewed as a model that carries out three directions: economic, socio-cultural, and environmental. With the support of a regulation and proper infrastructure development, the agro-tourism sector can promote and encourage energy efficiency and recycling. This all aims to avoid, reduce, and stop the pollution of the environment and the generation of waste.

In terms of a circular economy, agro-tourism is not only an environmental friendly form of tourism; it is also the link to redesigning the terms of consumption and waste for non-renewable energy sources. The goal is to follow agro-tourism activities through sustainable resource management. The key points are to re-use, recover, re-develop, regenerate and valorize the resources, having as frame of reference sustainability in agro-tourism.

Information and analysis of tourism demand and supply is very important because of the influence on policy development. These mark an impact on the environment, on agro-tourism economic activities, and on the socio-cultural identity. Therefore, the impact of agro-tourism activities requires adequate monitoring, evaluation and feed-back tools, through suitable indicators. It is important to have knowledge about the data and to start implementing actions to reduce negative impacts.

\section{Conclusions}

Achieving sustainable management in agro-tourism is a continuous process. This requires constant monitoring of the positive and negative impacts that contribute to the development of good practice to make agro-tourism a system that reaches sustainable development goals. Official criteria must be made available to the structures' managers, as individual actions cannot guarantee the sustainability of a sector. In this sense, the present article must be seen as an initial step of a multi-disciplinary research direction that has given as yet preliminary results, and the proposal of a new indicator to support the structures' managers.

This article, by questioning current issues and future possibilities, proposes ways in which the agro-tourism sector could be expanded, agreed upon, and made more viable and sustainable.

The interest focused on agro-tourism because of its contribution supporting the sustainable development of rural communities. The agro-tourism sector can represent an integral part of environmentally friendly activities. Reacting to the current of the socio-economic and environmental changes and technological challenges in a context of conserving the environment is a pivotal point.

In agro-tourism, special attention is required to the environment, which represents the "raw material", of tourism activity. Therefore, the relationship between agro-tourism and environment indicates a special significance; conserving and protecting the environment is the necessary condition for its practice.

Author Contributions: All the authors contributed equally to the present work.

Funding: This research received no external funding.

Conflicts of Interest: The authors declare no conflict of interest. 


\section{References}

1. European Commission. Environment Action Programme to 2020. Available online: http:/ / ec.europa.eu/ environment/action-programme/ (accessed on 15 January 2018).

2. United Nations. Economic and Social Council, Progress towards the Sustainable Development Goals. 2017. Available online: http:/ / www.un.org/ga/search/view_doc.asp?symbol=E/2017/66\&Lang=E (accessed on 15 January 2018).

3. World Commission on Environment and Development. Our Common Future, Oxford; Oxford University Press: New York, NY, USA, 1987.

4. Vergara, S.E.; Tchobanoglous, G. Municipal Solid Waste and the Environment: A Global Perspective. Annu. Rev. Environ. Resour. 2012, 37, 277-309. [CrossRef]

5. Morlok, J.; Schoenberger, H.; Styles, D.; Galvez-Martos, J.L.; Zeschmar-Lahl, B. The impact of pay-as-you-throw schemes on municipal solid waste management: The exemplar case of the county of Aschaffenburg, Germany. Resources 2017, 6, 8. [CrossRef]

6. Rada, E.C.; Cioca, L.I. Optimizing the metodology of characterization of Municipal Solid Waste in EU under circular economy perspectices. Energy Procedia 2017, 119, 72-85. [CrossRef]

7. Rada, E.C.; Cioca, L.I.; Ionescu, G. Energy recovery from municipal solid waste in EU: Proposals to assess the management performance under a circular economy perspective. MATEC Web Conf. 2017, 121, 05006. [CrossRef]

8. Giurco, D.; Herriman, J.; Turner, A.; Mason, L.; White, S.; Moore, D.; Klostermann, F. Integrated resource planning for urban waste management. Resources 2015, 4, 3-24. [CrossRef]

9. Pan, S.Y.; Gao, M.; Kim, H.; Shah, K.J.; Pei, S.L.; Chiang, P.C. Advances and challenges in sustainable tourism toward a green economy. Sci. Total Environ. 2018, 635, 452-469. [CrossRef] [PubMed]

10. Siemers, W. Sustainable tourism in Albania: Measures for energy, water and waste. GWF Wasser-Abwasser 2018, 159, 63-67.

11. Scuttari, A.; Orsi, F.; Bassani, R. Assessing the tourism-traffic paradox in mountain destinations. A stated preference survey on the Dolomites' passes (Italy). J. Sustain. Tour. 2018. [CrossRef]

12. Giurea, R.; Precazzini, I.; Ragazzi, M.; Achim, M.I. Criteria for environmental optimization of electrical and thermal energy in agro-tourism. In Proceedings of the 7th International Conference on Energy and Sustainability, Seville, Spain, 20-22 September 2017.

13. Williams, G. Economic impacts from development of the Coastal Town in Queensland on tourism and regional economy. Resources 2016, 5, 48. [CrossRef]

14. Serrano-Bernardo, F.A.; Bruzzi, L.; Marcucci, M.; Bonoli, A.; Rosúa-Campos, J.L. Making tourism more sustainable: The role of ecotourism and of other forms of green tourism. In Ecotourism: Practices, Benefits and Environmental Impacts; Nova Science Publishers, Inc.: New York, NY, USA, 2015; pp. 1-28.

15. Rada, E.C.; Zatelli, C.; Mattolin, P. Municipal Solid Waste selective collection and tourism? WIT Trans. Ecol. Environ. 2014, 180, 187-957. [CrossRef]

16. Shubov, L.Y.; Borisova, O.N.; Doronkina, I.G.; Chudaykina, G.M. An integrated approach to tourism development and environmental protection. World Appl. Sci. J. 2014, 30, 30-31. [CrossRef]

17. Ionescu, R.D.; Ragazzi, M.; Battisti, L.; Rada, E.C.; Ionescu, G. Potential of electricity generation from energy sources in standard domestic houses. WIT Trans. Ecol. Environ. 2013, 173, 245-253. [CrossRef]

18. Peeters, P.; Szimba, E.; Duijnisveld, M. Major environmental impacts of European tourist transport. J. Transp. Geogr. 2007, 15, 83-93. [CrossRef]

19. European Parliament. EPRS Tourism and European Union-Recent Trends and Policy Developments. 2015. Available online: http:/ / www.europarl.europa.eu/RegData/etudes/IDAN/2015/568343/EPRS_IDA(2015) 568343_EN.pdf (accessed on 15 January 2018).

20. European Parliament. Farm Diversification in the EU. 2016. Available online: http:/ / www.europarl.europa. eu/RegData/etudes/BRIE/2016/581978/EPRS_BRI(2016)581978_EN.pdf (accessed on 15 January 2018).

21. Giurea, R.; Ragazzi, M.; Zebres, M.V.; Achim, M.I. Is agro-tourism eco-frendly? MATEC Web Conf. 2017, 121, 10003. [CrossRef]

22. Phillip, S.; Hunter, C.; Blackstock, K. A typology for defining agritourism. Tour. Manag. 2010, 31, 754-758. [CrossRef] 
23. Rich, R.S.; Tomas, S.; Colucci, S.; Komar, S.; Schiling, B.; Carleo, J. Agritourism Opportunities for Farm Diversification. Available online: https://content.ces.ncsu.edu/agritourism-opportunities-forfarmdiversification (accessed on 15 January 2018).

24. European Union. Eurostat Statistics Explained, Tourism Statistics at Regional Level. 2016. Available online: http://ec.europa.eu/eurostat/statistics-explained/index.php/Tourism_statistics_at_ regional_level (accessed on 15 January 2018).

25. Chiran, A.; Vîntu, C.R.; Jitǎreanu, A.F.; Murariu, C.; Leonte, E. Possibilities for development of rural tourism and agro-tourism in Romania (case study). In Proceedings of the 29th International Business Information Management Association Conference-Education Excellence and Innovation Management through Vision 2020: From Regional Development Sustainability to Global Economic Growth, Vienna, Austria, 3-4 May 2017; pp. 234-241.

26. Giurea, R.; Ioan, A.M.; Ragazzi, M.; Cioca, L.I. Focusing agro-tourism structures for environmental optimization. Qual. Access Success 2017, 18, 115-120.

27. Autoritatea Nationala Pentru Turism, Romania. 2017. Available online: http://turism.gov.ro/legislatie/ (accessed on 15 January 2018).

28. European Commission. Agriculture and Rural Development-Italy. 2016. Available online: https: / / ec.europa.eu/agriculture/sites/agriculture/files/cap-in-your-country/pdf/it_en.pdf (accessed on 15 January 2018).

29. United Nations Environment Programme. A Manual for Water and Waste Management: What the Tourism Industry Can Do to Improve Its Performance. 2003.

30. European Parliament's Committee on Transport and Tourism. Research for Tran Committee-From Responsible Best Practices to Sustainable Tourism Development. 2016. Available online: http://www. europarl.europa.eu/RegData/etudes/STUD/2015/573421/IPOL_STU(2015)573421_EN.pdf (accessed on 15 January 2018).

31. Italian Institute of Statistics (ISTAT). Le Aziende Agrituristiche in Italia. Available online: http:/ / www.istat.it/it/files/2017/10/Le-aziende-agrituristiche-in-Italia_2016.pdf?title=Aziende+ agrituristiche+in+Italia+-+09\%2Fott\%2F2017+-+Le+aziende+agrituristiche+in+Italia_2016.pdf (accessed on 21 January 2018).

32. Romanian Statistical Yearbook (INSSE). Pensiuni Agroturistice. Available online: http://www.insse.ro/ cms/sites/default/files/field/publicatii/anuar_statistic_al_romaniei_2016_format_carte.pdf (accessed on 15 January 2018).

33. Eurostat. Share of Land Area According to the Original OECD Classification and the New Urban-Rural Typology. Available online: http:/ / ec.europa.eu/eurostat/statistics-explained/index.php/File:Share_of_ land_area_according_to_the_original_OECD_classification_and_the_new_urban-rural_typology_new.png (accessed on 15 January 2018).

34. Ranieri, E.; Montanaro, C.; Ranieri, A.C.; Campanaro, V.; Cioca, L.I. Municipal solid wastes in the South-Eastern Mediterranean region: Quality, quantity and management. Qual. Access Success 2017, 18, 162-169.

35. Nižić, M.K.; Grdić, Z.S.; Endres, R. Energy sustainability and its impacts on Croatian tourism. Croat. Econ. Surv. 2017, 19, 83-104. [CrossRef]

36. Qian, X.; Schneider, I.E. Waste minimization practices among tourism businesses: A multi-year comparison. Tour. Manag. Perspect. 2016, 19, 19-23. [CrossRef]

37. Mereu, S.; Sušnik, J.; Trabucco, A.; Daccache, A.; Vamvakeridou-Lyroudia, L.; Renoldi, S.; Virdis, A.; Savić, D.; Assimacopoulos, D. Operational resilience of reservoirs to climate change, agricultural demand, and tourism: A case study from Sardinia. Sci. Total Environ. 2016, 543, 1028-1038. [CrossRef] [PubMed]

38. Ionescu, G.; Rada, E.C.; Cioca, L.I. Municipal solid waste sorting and treatment schemes for the maximization of material and energy recovery in a latest EU member. Environ. Eng. Manag. J. 2015, 14, 2537-2544.

39. Ciudin, R.; Isarie, C.; Cioca, L.I.; Petrescu, V.; Nederita, V.; Ranieri, E. Vacuum waste collection system for an historical city centre. UPB Sci. Bull. Ser. D 2014, 76, 215-222.

40. Martini, U.; Buffa, F.; Notaro, S. Community participation, natural resource management and the creation of innovative tourism products: Evidence from Italian networks of reserves in the Alps. Sustainability 2017, 9 , 2314. [CrossRef] 
41. Sidali, K.L.; Huber, D.; Schamel, G. Long-term sustainable development of tourism in South Tyrol: An analysis of tourists' perception. Sustainability 2017, 9, 1791. [CrossRef]

42. Privitera, D.; Nedelcu, A.; Nicula, V. Gastronomic and food tourism as an economic local resource: Case studies from Romania and Italy. Geoj. Tour. Geosites 2017, 21, 143-157. [CrossRef]

43. Dulǎu, A.V.; Coroş, M.M. Is cultural tourism attractive in Transylvania? A focus on Cluj and Sibiu counties, Romania. WSEAS Trans. Bus. Econ. 2009, 6, 413-424.

44. Yadav, P.; Samadder, S.R. Assessment of applicability index for better management of municipal solid waste: A case study of Dhanbad, India. Environ. Technol. 2018, 39, 1481-1496. [CrossRef] [PubMed]

45. Kasam; Mulya Iresha, F.; Ajie Prasojo, S. Evaluation of solid waste management at campus using the "zero Waste Index": The case on campus of Islamic University of Indonesia. MATEC Web Conf. 2018, 154, 02004. [CrossRef]

46. Rada, E.C.; Zatelli, C.; Cioca, L.I.; Torretta, V. Selective collection quality index for municipal solid waste management. Sustainability 2018, 10, 257. [CrossRef]

47. Godura, S.; Aggarwal, A.K.; Bhatia, P. Municipal solid waste management index in urban areas: Delphi validated tool. Int. J. Environ. Waste Manag. 2017, 20, 215-232. [CrossRef]

48. Trentino Agricoltura. 2016. Available online: http://www.trentinoagricoltura.it/Trentino-Agricoltura/Areetematiche/ Agriturismo (accessed on 15 January 2018).

49. INSSE Institutul Naţional de Statistică. 2016. Available online: http:/ / statistici.insse.ro/shop/index.jsp? page $=$ tempo2\&lang $=$ ro\&context $=63$ (accessed on 15 January 2018).

50. Lakatos, E.S.; Cioca, L.I.; Dan, V.; Ciomos, A.O.; Crisan, O.A.; Barsan, G. Studies and investigation about the attitude towards sustainable production, consumption and waste generation in line with circular economy in Romania. Sustainability 2018, 10, 865. [CrossRef]

51. Benyam, A.; Kinnear, S.; Rolfe, J. Integrating community perspectives into domestic food waste prevention and diversion policies. Resour. Conserv. Recycl. 2018, 134, 174-183. [CrossRef]

52. Neugebauer, M.; Sołowiej, P. The use of green waste to overcome the difficulty in small-scale composting of organic household waste. J. Clean. Prod. 2017, 156, 865-875. [CrossRef]

53. Vázquez, M.A.; Soto, M. The efficiency of home composting programmes and compost quality. Waste Manag. 2017, 64, 39-50. [CrossRef] [PubMed]

54. Torretta, V. Environmental and economic aspects of water kiosks: Case study of a medium-sized Italian town. Waste Manag. 2013, 33, 1057-1063. [CrossRef] [PubMed]

55. Martinez-Sanchez, V.; Levis, J.W.; Damgaard, A.; DeCarolis, J.F.; Barlaz, M.A.; Astrup, T.F. Evaluation of Externality Costs in Life-Cycle Optimization of Municipal Solid Waste Management Systems. Environ. Sci. Technol. 2017, 51, 3119-3127. [CrossRef] [PubMed]

56. JRC-EU. Available online: http://ec.europa.eu/environment/emas/takeagreenstep/pdf/BEMP-6-FINAL. pdf (accessed on 2 August 2018). 